\title{
Martyna Sadowska*
}

AGH Akademia Górniczo-Hutnicza w Krakowie

ORCID 0000-0002-2400-4984

\section{„KULTURA PRZEGRYWU” I [BEEP] GENERATION NA PRZYKŁADZIE TWÓRCZOŚCI POETYCKIEJ TOMASZA BĄKA ${ }^{1}$}

\begin{abstract}
W artykule pragnę skupić się na zjawisku, które w potocznej świadomości społecznej funkcjonuje jako „kultura przegrywu". Ponadto celem niniejszych przemyśleń będzie charakterystyka nietypowej społeczności „ludzi przegrywów" oraz jej najbardziej rozpoznawalnego antybohatera, przez Tomasza Bąka określanego mianem „,człowiek pizda”. Przykładem, na którym pragnę oprzeć interpretację poruszanych zagadnień należących do szeroko pojętego „przegrywu” będzie twórczość poetycka współczesnego, polskiego poety, wspomnianego już Tomasza Bąka. Punktem wyjścia moich przemyśleń będą następujące pytania o charakterze fundamentalnym: (1) Czy zjawisko „kultury przegrywu” faktycznie zaistniało w Polsce? (2) Jeśli tak, to czym jest i jakie są jej cechy charakterystyczne? (3) Kim są bohaterowie społeczności „przegrywu” oraz „człowiek pizda”? (4) Jakie konsekwencje społeczne, ekonomiczne, polityczne i kulturowe niesie ze sobą omawiane zjawisko?

Mam nadzieję, że odpowiedź na wyżej wymienione problemy pozwoli na wydobycie nietypowości zjawiska wciąż rozwijającego się w Polsce.
\end{abstract}

Słowa kluczowe: aktywność, opór, kultura przegrywu, [beep] generation, człowiek pizda, bierność

\section{„KULTURA PRZEGRYWU” - „PRZEGRYWY” - „CZŁOWIEK PIZDA”. ZARYS PROBLEMU}

Co najmniej od ostatnich dwudziestu lat można obserwować istotne, specyficzne zmiany, jakie zachodzą we współczesnej, polskiej kulturze i społeczeństwie. Wydaje się, że obecnie w Polsce mamy do czynienia z procesem powolnego „rozszczelniania” społeczno-kulturowego centrum tworzonego przez osoby z wielkimi aspiracjami, tzw. ludzi sukcesu spełnionych życiowo i konsekwentnie dążących do osiągnięcia postawionych sobie celów. W tę sferę szczególnej

* Adres do korespondencji: Martyna Sadowska, AGH Akademia Górniczo-Hutnicza, Wydział Humanistyczny, Katedra Politologii i Historii Najnowszej, ul. Gramatyka 8a, 30-071 Kraków; e-mail: sadowska.martyna@ o2.pl.

1 Artykuł powstał na podstawie mojej nieopublikowanej pracy magisterskiej pt. Aktywność w bierności - przyczynek do badań figury podmiotu młodego pokolenia na przykładzie twórczości poetyckiej Tomasza Bąka. 
widoczności społecznej coraz częściej wkraczają podmioty dotąd marginalizowane, których egzystencja jest dla społeczeństwa synonimem porażki: ekonomicznej, politycznej, społecznej i kulturowej. Zjawisko to można zaobserwować przede wszystkim w mało popularnych działaniach społeczno-artystycznych, które ze względu na swój „oddolny” charakter nadają procesowi włączania marginesów do społecznego centrum cech subwersywnych, o czym będzie jeszcze mowa w dalszych rozważaniach. W Polsce kwestia specyficznej zmiany podejścia do porażki i ludzi ją utożsamiających zyskuje na popularności, przekracza tym samym swoją „niszowość” i wchodzi w obręb współczesnej kultury oficjalnej, szczególnie „widocznej”, współtworzonej przez różnego rodzaju media (zwłaszcza internetowe).

Stąd też celem niniejszego artykułu będzie próba scharakteryzowania specyficznych strategii kulturowych, które, moim zdaniem, składają się na tzw. „kulturę przegrywu” wytwarzaną przez ludzi urodzonych w latach 80. i 90. XX wieku. Grupę tę polski poeta Tomasz Bąk określa mianem ,[beep] generation” i w swoim tomiku wierszy o tym samym tytule kreuje postać najbardziej z nich żenującą, zawstydzającą i wzbudzającą wstręt otoczenia, będącą ucieleśnieniem całkowitej porażki - „człowieka pizdę”.

Te problemy poruszane na poziomie języka (m.in. śledzenie automatyzmów językowych, zwracanie uwagi na budowanie fałszywych pojęć i szkodliwych skrótów myślowych) oraz w przedstawianej wizji współczesnego świata (m.in. zagubienie jednostek w chaotycznej rzeczywistości owładniętej przez niejasne prawa rynku i ekonomii) wpisują twórczość Tomasza Bąka w obręb ,poezji zaangażowanej”. Najogólniej rzecz ujmując, chodzi o taki typ poetyckiej narracji, w ramach której podmioty wyrażają określone stanowiska ideowo-polityczne oraz zostają zdemaskowane poszczególne zasady działania szeroko pojętej polityki (Czapliński 2013: 79-90). Piotr Śliwiński postrzega Tomasza Bąka jako twórcę krytycznego o lewicowych poglądach, który co prawda nie angażuje się bezpośrednio w realizacje konkretnych projektów społecznych (Śliwiński 2019), jak np. Szczepan Kopyt czy Konrad Góra, ale za to porusza istotne tematy społeczno-polityczne w sposób kunsztowny i przemyślany, o czym może świadczyć m.in. przyznanie Bąkowi Wrocławskiej Nagrody Poetyckiej Silesius w 2012 roku za debiutancki tomik pt. Kanada (Kaczmarski i Koronkiewicz 2016: 96) oraz nominacja do Nagrody im. Wisławy Szymborskiej właśnie za zbiór wierszy [beep] Generation. Uważam, że w tym dziele poeta najpełniej oddał to, czym jest ,przegrana społeczność” i wytwarzana przez nią ,kultura przegrywu”.

Warto zaznaczyć, że tego pojęcia nie należy w całości utożsamiać z szeroko rozumianą „kulturą porażki”. W ramach tej drugiej losy jej przedstawicieli prezentują się różnie: sama przegrana może mieć charakter nie tylko deprecjonujący, ale również dowartościowujący podmiot, który choć przegrał, to mógł odnieść np. moralne zwycięstwo. „Kultura przegrywu" zaś w zaproponowanym przeze mnie ujęciu dotyczy porażki najbardziej uwłaczającej, pozbawionej jakichkolwiek nobilitujących wartości. „Przegrywy” to osoby wyrzucone przez ogół społeczeństwa na „śmietnisko” kultury, skompromitowane pod każdym względem: politycznym, ekonomicznym, społecznym, a nawet fizycznym. Ich żałosną pozycję podkreśla i umacnia wspomniany już antybohater: „,człowiek pizda”, znany też w polskiej popkulturze jako m.in. „frajer” (zob. Miejski stownik slangu i mowy potocznej 2019), ,ciamajda, niezdara” (Czeszewski 2006: 234).

Ze względu na ograniczoną formę artykułu nie można wyczerpująco omówić wszystkich poruszanych zagadnień, niemniej jednak, aby w miarę możliwości odpowiednio zinterpretować 
podane zjawiska, należałoby zacząć od odpowiedzi na pytanie, gdzie i w jaki sposób szukać śladów tego specyficznego rodzaju kultury w Polsce. Następnie trzeba przystąpić do próby uchwycenia charakterystyki samej społeczności „przegrywu” oraz ich najbardziej typowego antybohatera: spróbować ich zdefiniować i wyłonić cechy charakterystyczne. Rozważania te z kolei powinny zamknąć przemyślenia na temat konsekwencji kulturowych, społecznych, ekonomicznych i gospodarczych, jakie niesie z sobą omawiane zjawisko we współczesnej Polsce.

KOMENTARZ METODOLOGICZNY. NAJWAŻNIEJSZE NARZĘDZIA BADAWCZE

Realizacja powyższych punktów badawczych wymaga użycia odpowiednich narzędzi metodologicznych. W niniejszym artykule pragnę spojrzeć na „kulturę przegrywu” przede wszystkim przez pryzmat takich kategorii, jak: antybohaterskość, Nikt i Każdy, obciach, wstręt, frustracja, agresja, opór, aktywność, bierność - w perspektywie literaturoznawczej i antropologiczno-kulturowej.

Pierwsze z wymienionych zagadnień, czyli pojęcie „antybohatera”, dobrze definiuje Michał Wolski (Wolski 2016: 36-47) jako:

postać (literacką, serialową, komiksową itp.), która ze względu na swoje działania i zachowania może budzić u odbiorcy poczucie niechęci lub wręcz odrazy; postać nieatrakcyjną, często amoralną (lub posługującą się własnym, nieraz podyktowanym konformizmem rozumieniem moralności) i niewypełniającą - albo robiącą to niewłaściwie - ról społecznych, które są jej powierzone. Jednocześnie jednak narracja w danym tekście kultury jest tak dalece spersonalizowana, że narzuca odbiorcy mechanizm projekcji-identyfikacji wbrew ewentualnym awersjom.

Tak rozumiany antybohater jest identyczny z figurą wykreowaną przez Tomasza Bąka w jego tomiku [beep] Generation. Warto zwrócić uwagę również na ostatnią część podanego przez Wolskiego wyjaśnienia. Badacz podkreśla specyficzny rodzaj utożsamienia się odbiorców niejako na przekór ich własnej woli z przedstawianym antybohaterem, jakkolwiek by był odpychający.

Tę ambiwalentną relację, opierając się na pojęciu wstrętu Julii Kristevej, dobrze opisała Anna Figa w swojej refleksji nad kwestiami „Nikogo” i „Każdego” (Figa 2015: 393-301):

Byt Każdego charakteryzuje jego pozorna zwyczajność, brak cech szczególnych, jakiegokolwiek zindywidualizowanego rysu [podkr. własne]. Everyman tworzy siebie przez niwelację wyróżnienia, wskutek niedosłownej, charakterologicznej mimikry - procesu upodabniającego go do ogółu. [...]

Nikt stanowi swoisty - lecz jedynie możliwy, a nie obligatoryjny - punkt dojścia dla everymana; bynajmniej nie jest jego synonimem. [...] Nikt z pozoru wydaje się typem postaci odzwierciedlającym zupełnie odmienne procesy odbioru: nie sugeruje podobieństwa, nie tworzy - opartej na bliskości bytów - nici porozumienia pomiędzy sobą a odbiorcą. Wrażenie to jest jednak pozorne. Nikt może być także Każdym [podkr. własne]. On również przypomina nam nas samych, jednak czyni to nie przez wskazanie na przeciętność bądź brak cech zindywidualizowanych. 
Tak zdefiniowane przez Figę pojęcia pomogą lepiej zinterpretować złożoność relacji między większością społeczeństwa a członkami [beep] generation oraz „wypikanego pokolenia $^{2}$ (określenia tego używa np. Marta Koronkiewicz w szkicu o poezji Tomasza Bąka, zob. Kaczmarski i Koronkiewicz 2016: 99) względem swojego antybohatera: „człowieka pizdy”.

Perspektywa posiadania cech wspólnych z antybohaterskim „Nikim”, „,złowiekiem pizdą”, czy członkiem odrzuconej wspólnoty [beep] napawa ludzi stojących wyżej w hierarchii społecznej wstrętem i każe myśleć o jednostkach zmarginalizowanych w kontekście „obciachu”.

Słowo to początkowo używane w więziennej grypserze, później przechwycone przez młodzież do swojego slangu, współcześnie jest przede wszystkim kategorią wartościującą poszczególne jednostki oraz umacniającą pozycję uprzywilejowanej społecznie grupy, która wyznacza aktualne granice tego, co „obciachowe” (Pęczak 2009). Ponadto na „obciach” (Januszkiewicz 2008: 36) należy spojrzeć jak na pojęcie:

nacechowane negatywnie pod względem aksjologicznym i polegające na tym, że jakiś podmiot w sposób nieświadomy przekracza przyjętą w danej społeczności (kulturze), do której przynależy, normę, co prowadzi go w oczach odbiorcy do kompromitacji, budząc w nim uczucia wstydu i śmieszności, a w odbiorcy - uczucia zakłopotania i drwiny.

Jednostki kreujące społeczno-kulturowe centrum odczuwają paniczny lęk przed włączeniem ich w obręb obciachowej wspólnoty [beep] generation. Odkrycie cech wspólnych między osobami dominującymi w kulturze a „człowiekiem pizdą” wywołuje w podmiotach tych wspomniane już uczucie wstrętu (Menninghaus 2009: 244-245), które:

rodzi się w miejscu pęknięcia, ba, j a k o miejsce pęknięcia pomiędzy naturą a kulturą. Jest „symptomem obrony" przed naturą, do której [wstręt - dopisek własny] bywał niejednokrotnie zaliczany na skutek swej przynależności do „niższych” $i$,,ciemnych” zmysłów.

Wstręt odczuwany przez jednostki uprzywilejowane w hierarchii społecznej uprzedmiatawiają [beep] generation i „człowieka pizdę”, a następnie umieszczają ich w polu natury zagrażającej ogółowi społeczeństwa. Znaczenie „wstrętności” nie wyczerpuje się jednak w powyższej definicji. Aby lepiej zrozumieć mechanizmy hierarchizacji i odrzucenia obowiązujące w świecie wykreowanym przez Tomasza Bąka, należy przywołać koncepcję abjektu Julii Kristevej.

Abjekt, inaczej „wymiot”, jest wszystkim tym, co odrzucone, wydalone, obce naszemu ciału, a co budzi odrazę i chęć dominacji, zdyscyplinowania (np. wydzieliny cielesne). Tego, co kryje się pod pojęciem badaczki, nie można przyswoić ani całkowicie się pozbyć z przestrzeni kulturowej (Łebkowska 2011: 11-27). Analogicznie prezentuje się sytuacja [beep] generation i „człowieka pizdy” względem społeczeństwa. W świecie stworzonym przez Bąka dominująca większość pragnie pozbyć się z obszaru widoczności „obciachowych jednostek", co jednak nie może dojść do skutku: członkowie zmarginalizowanej społeczności współtworzą społeczną tkankę, warunkują jej istnienie.

2 Tego określenia używają krytycy współczesnej literatury polskiej, np. Tomasz Cieślak (zob. Cieślak, źródło: https://www.e-kalejdoskop.pl/literatura-a215/wszystko-beep-r5048/pdf ) lub Marta Koronkiewicz (zob. Kaczmarski i Koronkiewicz 2016: 99). 
Konieczność konfrontowania się społeczeństwa ze wstrętnymi podmiotami to jedna z przyczyn rodzących się zarówno u jednych, jak i drugich agresji i frustracji. Tę ostatnią należy rozumieć m.in. jako stan po uświadomieniu sobie przeszkód, które nie pozwalają osiągnąć spodziewanego celu (Taras 2012: 7).

Wszystkie z poruszonych dotychczas kwestii i pojęć wskazują na ogromną siłę oddziaływania [beep] generation i „człowieka pizdy” na społeczeństwo. Ten specyficzny rodzaj oporu stawianego swoim odbiorcom oraz wpływ, jaki wywierają ,,przegrywy” na „,kulturowe centrum” i zasady społecznego funkcjonowania, każą spojrzeć na „człowieka pizdę”, społeczność [beep] i wreszcie na samą „kulturę przegrywu” w perspektywie subwersywnej.

Kolejnym elementem służącym lepszemu zbadaniu rzeczywistości „ludzi przegrywów” jest więc subwersja. Łukasz Ronduda przedstawia ją jako rodzaj postawy krytycznej, która formułuje swój opór względem kulturowego centrum z wnętrza kultury dominującej (Ronduda 2006: 9). Strategie subwersywne nie są oderwane od tego, co oficjalne, a ich działanie polega na (Dziamski 2001):

naśladowaniu, utożsamianiu się niemalże z przedmiotem krytyki, a następnie delikatnym przesunięciu znaczeń. Ten moment przesunięcia znaczeń nie zawsze jest uchwytny dla widza. To nie jest krytyka wprost, bezpośrednia, tylko krytyka pełna dwuznaczności, odwołująca się do pewnego sekretnego porozumienia z widzem, który musi podążać za myślą autora, a bardzo często sam skonstruować krytyczny sens pracy.

„Kultura przegrywu” mimo swojego „oddolnego”, „niszowego” charakteru przedostaje się do kulturowego centrum i wywiera na niego istotny wpływ, dlatego kwestia subwersji nie może zostać pominięta $\mathrm{w}$ dalszej części rozważań.

Wszystkie poruszone powyżej zagadnienia prowadzą z kolei do innego ważnego problemu specyficznego świata ludzi przegranych: koncepcji „przedziwnej sztuki porażki” Jacka Halberstama (zob. Halberstam 2018). Amerykański kulturoznawca w swoich rozważaniach postuluje stawianie na to, co naiwne i niedorzeczne (głupie), odrzucenie mistrzostwa, krytykę intuicyjnie kreślonych w kapitalizmie połączeń między sukcesem i zyskiem. Samą porażkę badacz przedstawia jako doświadczenie pozytywne, dzięki któremu podmiot może uciec przed normami dyscyplinującymi zachowanie i rozwój człowieka (Halberstam 2018: 15-16). Halberstam poszukuje w ,przegranej” jej wywrotowego potencjału, który pomógłby w zmianie dotychczasowego opresyjnego systemu kładącego nacisk na sukces i „pozytywne myślenie” (Stępniak 2019: 1-13). Badacz nie boi się sięgać w swojej interpretacji zjawiska porażki po przykłady ze sztuki o różnym poziomie wyrafinowania. Halberstam stosuje się do własnych tez i udowadnia, że nie należy ignorować żadnego zjawiska w kulturze, nawet jeżeli zostało ono przez społeczeństwo zdeprecjonowane, ośmieszone. W tym miejscu warto podkreślić, że poglądy amerykańskiego badacza na kwestię „,przegranej” oparte są przede wszystkim na sztuce i teorii queer oraz krytyki feministycznej, co jest oczywiście niezwykle cenne, ale równocześnie znacznie zawęża problematykę porażki. Stąd też mam nadzieję, że każde z wymienionych dotychczas zagadnień antropologicznych, kulturowych czy socjologicznych ułatwią charakterystykę ,ludzi przegrywów”, ich styl bycia i wynikające z niego konsekwencje w szerszej perspektywie. Ponadto warto dodać, że perspektywa badań porażki na gruncie amerykańskim zaproponowana przez Halberstama jest ważna również w badaniach nad polską 
„,kulturą przegrywu”, chociażby ze względu na to, jak silny wpływ wywiera kultura Ameryki na rzeczywistość społeczno-kulturową w Polsce. Nie ulega wątpliwości, że należy rozważyć, czy problem polskiej porażki posiada jakieś cechy odróżniające ją od amerykańskiej i jeśli tak: poddać te elementy dokładnej analizie.

\section{„KULTURA PRZEGRYWU”W POLSCE - NAKREŚLENIE OBSZARU BADAWCZEGO}

Materiał badawczy, na podstawie którego można zaobserwować formy występowania „kultury przegrywu”, jest obszerny i dotyczy wielu dziedzin: literackich, muzycznych, internetowych. Ta ostatnia z powodu swojej popularności, wysokiego, łatwego poziomu dostępu dla niemal każdego użytkownika, to szczególnie wyraziste i ważne źródło informacji o specyfice rzeczywistości „przegrywów”.

Internetowa sztuka wizualna oprócz funkcji rozrywkowej odgrywa też rolę specyficznego lustra, w którym odbija się rzeczywistość jej użytkowników. Nie inaczej jest w przypadku „kultury przegrywu”. W internecie można odnaleźć liczne do niej odniesienia, zaczynając od najprostszych memów, demotywatorów, a na ambitnych, dużych projektach z pogranicza wizualności i literackości kończąc. Do tych ostatnich niewątpliwie należałoby zaliczyć: ironiczne rysunki z komentarzami typu „Czynny żal” Małgorzaty Halber, fanpage „Chujowa Pani Domu” Magdaleny Kostyszyn, czy wreszcie takie projekty, jak: „Magazyn Porażka” Kamila Fejfera, „Zjebane życie” czy fanpage „Ponuro mi” Pawła Żukowskiego.

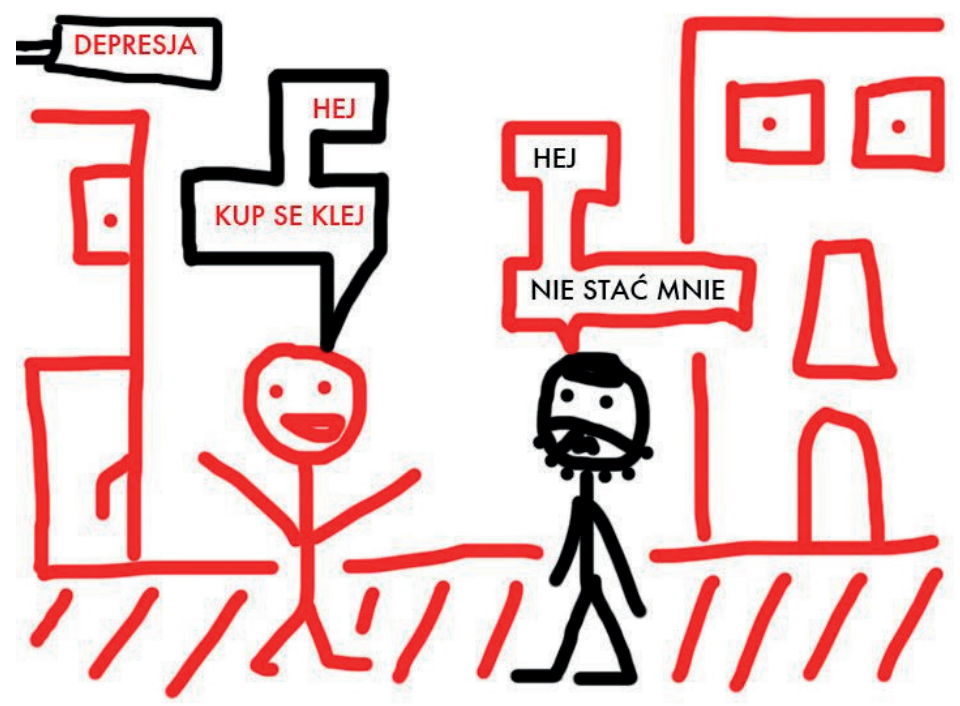

Rysunek 1. Paweł Żukowski, komiksowy rysunek z fanpage'a „Ponuro mi” Źródło: https://www.facebook.com/ponuromi/ 
Rysunek Pawła Żukowskiego z fanpage’a „Ponuro mi” (rysunek 1) doskonale odzwierciedla charakter „kultury przegrywu”: jej „obciachowość” oraz autoironiczny stosunek, dystans do kultury oficjalnej. Wybór wszystkich przytoczonych powyżej twórców i ich projektów jest oczywiście subiektywny i arbitralny, niemniej jednak zdaje się dobrze prezentować cechy szeroko pojętego ,przegrywu”.

Również w muzyce popularnej można odnaleźć narracje charakterystyczne dla „kultury porażki”. Przykładem tego może być polski zespół punkowy Cool Kids of Death, który w 2002 roku wydał swój pierwszy album muzyczny. W piosence pt. Generacja nic Krzysztof Ostrowski śpiewał (Cool Kids of Death 2002):

\author{
Generacja nic \\ Generacja nie \\ Generacja nikt \\ Generacja źle \\ To nie może się udać \\ To się kończy źle
}

Co ciekawe, dziesięć lat później basista CKOD Jakub Wandachowicz (2012) napisał do „Gazety Wyborczej” o ludziach urodzonych w połowie lat 80. ubiegłego wieku następująco:

To pokolenie, które nazywam ,generacją nic”, jest pokoleniem o tyle specyficznym, że podczas gdy represje towarzyszące życiu innych generacji miały związek z różnego rodzaju ograniczającym zniewoleniem (wojny, totalitaryzmy), to dziś młodość przegrywa $\mathbf{z}$ tą wolnością, o którą w przeszlości toczyła się walka. Wolność w naszych czasach zaczęla oznaczać intelektualną pustkę ludzi młodych, którzy nie chcą uczestniczyć w żadnym dyskursie [podkr. własne].

Minęło sześć lat od artykułu Wandachowicza i w 2018 roku dwóch hiphopowców: Filip Tadeusz Szcześniak znany jako Taco Hemingway oraz Kuba Grabowski występujący pod pseudonimem Quebonafide w singlu z płyty Soma 0,5 $\mathrm{mg}$ rapują: „Nasze pokolenie Tamagotchi” i dalej: „Tylko pić, jeść, spać, jak Tamagotchi” (Taconafide 2018). Ciekawe, że o ile piosenka Generacja nic została obejrzana przez internautów na YouTubie około 55,5 tysiąca razy (27.11.2019), o tyle utwór Szcześniaka i Grabowskiego ma już prawie 70 milionów wyświetleń (27.11.2019), zaś album Soma 0,5 mg przyniósł jej wykonawcom złotą i liczne platynowe płyty, a Taconafide uchodzi obecnie za jeden z najpopularniejszych duetów raperskich w Polsce. Oznacza to, że zaproponowana przez członków zespołu Cool Kids of Death narracja o jakiejś specyficznej, „,wiecznie niewłaściwej” generacji pustoty i pustki nie przedawniła się, a wręcz przeciwnie: powróciła w nieco zmienionej formie, w treściach i stylu zaproponowanym przez Quebonafide, a zwłaszcza Taco Hemingwaya, i stała się jeszcze popularniejsza wśród Polaków.

Tego typu wątki funkcjonujące w obrębie ,kultury przegrywu” można odnaleźć również w twórczości bardzo ważnej postaci dla polskiego rynku kulturowego, mianowicie u Doroty Masłowskiej. W jej działalności artystycznej kwestie ludzi przegranych są doskonale widoczne zarówno w projektach muzycznych (D. Mister Społeczeństwo jest niemiłe), jak i literackich (m.in. Paw królowej, Kochanie, zabiłam nasze koty). Warto w tym miejscu wyróżnić najnowsze dzieło Doroty Masłowskiej: Innych ludzi. Co ciekawe, jego wydanie było 
połączone z wypuszczeniem hiphopowego klipu na YouTubie, który miał promować jej książkę w 2018 roku. Bohaterowie tej powieści, pod każdym względem niespełnieni, znajdujący się na dnie społecznej hierarchii, włączają zasady rządzące rynkiem kapitalistycznym do każdej dziedziny swojego życia. Postacią, która najpełniej oddaje kwestie ,,przegrywu” w dziele Masłowskiej, jest Kamil, co dobrze widać w następującym fragmencie:

On pisze „huj” w windzie, jak nią jedzie na jeszcze lekkiej zmiksie, musi się ogolić, wysrać, co dalej z jego życiem przemyśleć.

Możliwe, że je przegral, ktoś sobie pomyśli po tym wszystkim, pozakładali rodziny wszyscy albo praca w myjni, tiry na Wyspach.

Niby on z matką mieszka, ale marzeniami żyje artysty, albumu wizją [podkr. własne]

(Masłowska 2018: 152).

Powyższe przykłady to jedynie część propozycji, jakie należało wymienić, omawiając zagadnienie ,kultury przegrywu”. W subiektywnym wyborze niniejszych dzieł najważniejszym kryterium było wydobycie wspólnych tendencji dla każdego z utworów, które moim zdaniem poruszają tematykę ,przegrywu”, a które robią to w sposób niekonwencjonalny. Ponadto starałam się, by zaproponowane pozycje pochodziły z różnych dziedzin społeczno-kulturowej codzienności, co pozwoli na nakreślenie pełniejszego obrazu rzeczywistości „przegrywów” w Polsce.

Jak widać, bogactwo, różnorodność i kontrowersyjność „kultury przegrywu” ma swoje rozmaite formy $\mathrm{w}$ dziełach z przestrzeni internetu, muzyki i literatury: zarówno w prozie, jak i poezji. Tej ostatniej, choć mniej popularnej, nie można pominąć w analizie zjawiska „sztuki przegrywu”. Paradoksalnie to za pomocą języka poetyckiego zostanie przedstawiony niezwykle złożony, szczegółowy, intrygujący, budzący kontrowersje opis „ludzi przegrywów” i ich rzeczywistości. Wspomniany już przeze mnie Tomasz Bąk, autor tomiku [beep] Generation, zdaje się najlepiej i najpełniej oddawać wizerunek rodzącej się współcześnie grupy społecznej, dlatego twórczość ta posłuży za podstawę niniejszej analizy omawianych zjawisk.

\section{WIZERUNEK „LUDZI PRZEGRYWÓW” W PERSPEKTYWIE POEZJI TOMASZA BĄKA}

Jednym z głównych tematów tomiku poetyckiego z 2016 roku polskiego poety jest zbiorowość, „ludzie przegrywy” urodzeni prawdopodobnie w latach 90 . XX wieku, po studiach, którzy wkroczyli lub starają się wkroczyć na aktualny rynek pracy w Polsce. Ich sytuacja finansowo-egzystencjalna jest wysoce niestabilna: pracują przeważnie w korporacjach na umowie zleceniu, poniżej swoich kwalifikacji za marne wynagrodzenie, które uniemożliwia im rozpoczęcie samodzielnego życia (uniezależnienia się od rodziców, wyprowadzenia się $\mathrm{z}$ domu rodzinnego).

Sytuacja wypikanego pokolenia spycha tę grupę poza społeczny nawias. Tomasz Bąk już samym tytułem swojego dzieła deprecjonuje określoną tym mianem społeczność. Onomatopeja [beep], sygnał ocenzurowanego przekleństwa, który można usłyszeć np. w telewizji lub niektórych internetowych produkcjach, podkreśla niemożność wypowiedzenia prawdziwych myśli członków środowiska „kultury przegrywu” na temat swojej aktualnej sytuacji. 
Ich wypowiedzi są zdyscyplinowane przez system, który nie pozwala jednostkom na jawne wyrażanie sprzeciwu względem zastanej rzeczywistości.

Ludzie opisywani przez Bąka jako „,[beep] generation”, których ja określam mianem „przegrywów”, to grupa osób skoncentrowana na skrupulatnym wypełnianiu odgórnie narzuconych im ról społecznych, egzystencjalnych, zawodowych, które nie dają im życiowej satysfakcji, szczęścia ani poczucia bezpieczeństwa:

\author{
Poznaj Monikę, która parzy kawę w korpo. \\ miałaby depresję, ale nie ma czasu na depresję [podkr. własne] \\ (jak powszechnie wiadomo, \\ na forach \\ dla samobójców piszą wyłącznie ludzie sukcesu).
}

mogłaby się wkurwić, ale stawia na sznur [podkr. własne] (Bąk 2016: 43).

Wypikane pokolenie jest całkowicie podporządkowane szeroko pojętemu systemowi społecznemu. Wiedzeni strachem przed niepewną przyszłością wolą poddać się zewnętrznemu naciskowi i wymaganiom społecznym, by nie utracić i tak już marnej pozycji w społeczeństwie. Grupa „ludzi przegrywów” nie podejmuje nawet prób buntu, ponieważ i tak nikt nie liczy się z ich opiniami.

Ponadto tragedią wypikanego pokolenia jest bolesna samoświadomość sytuacji, w jakiej się znaleźli. Rzeczywistość [beep] generation to świat korporacji i bezdusznego, zmitologizowanego rynku, który dokonuje weryfikacji wartości człowieka na podstawie jego atrakcyjności fizycznej, materialnej, nie zaś duchowej czy moralnej, z czego członkowie wypikanego pokolenia doskonale zdają sobie sprawę. Co więcej, ludzie ci mają poczucie braku możliwości samorealizacji i bezużyteczności wykonywanych prac, które są zwykle poniżej ich kwalifikacji lub całkowicie się z nimi rozmijają. Świadomość złej sytuacji społecznej, ekonomicznej, egzystencjalnej wzbudza wśród członków [beep] generation nieustanne poczucie frustracji. Wewnętrzna niezgoda na aktualny stan swojego życia przy wypełnianiu narzuconego skryptu kulturowego nie doprowadza wypikanego pokolenia do wprowadzenia jakichś konstruktywnych zmian w swojej rzeczywistości. Zachowanie za wszelką cenę nikłego poczucia bezpieczeństwa, jakiego w danej chwili udziela im rynek/ system/ władza, oraz pragnienie prowadzenia wygodnego życia są silniejsze niż wartości moralne (jak np. poczucie godności, własnej wartości) czy marzenia niewpisujące się w społeczny schemat narzuconych pragnień:

Poeci [beep] generation.

Jeśli grają w kapelach, to tylko

weselnych, bo hajs.

Jeśli piszą artykuły, to tylko

sponsorowane, bo hajs.

Jeśli sprzątają mieszkanie, to tylko

cudze, bo hajs albo brak hajsu (Bąk 2016: 42).

Narastająca pokoleniowa frustracja, poczucie rozczarowania, świadomość daremności podejmowanych wysiłków (Taras 2012: 7) i maskowana pogarda względem samego siebie niosą za sobą dalsze konsekwencje. Poczucie posiadania życia pozbawionego głębszych 
wartości oraz szeroko pojęte niespełnienie w końcu doprowadza członków [beep] generation do agresji. Niestety nawet ona nie jest w stanie wyprowadzić „ludzi przegrywów” z ich życiowego marazmu. Agresywność w przypadku tych podmiotów-frustratów nie ma ujścia na zewnątrz: to dalej karni pracownicy posłuszni restrykcjom społecznym. Wściekłość członków wypikanego pokolenia przejawia się przede wszystkim w ich licznych fantazjach o przemocy, nie zaś w czynach. Bohaterowie [beep] generation skupiają się na marzeniach o radykalnym unicestwieniu otaczającej ich rzeczywistości: ludzi, miast, miejsc pracy itp.

Charakter wizji snutych przez wypikaną generację został dobrze oddany przez Tomasza Bąka w jego wierszach za pomocą specyficznego, niezwykle wulgarnego języka. Zabiegi poety Marta Koronkiewicz określiła jako zastosowanie przez niego „retoryki wkurwu” (Koronkiewicz 2016: 99). Autor tomiku [beep] Generation prezentuje swoim czytelnikom szeroki przekrój polskich wulgaryzmów: od tych najbardziej znanych i oczywistych, aż po wyszukane, niesmaczne obelgi, biologizmy, jak w utworze pt. Wiersz wspólfinansowany ze środków Unii Europejskiej w ramach Europejskiego Funduszu Rozwoju Regionalnego:

Korek? Rzuć psom miasto.

Spuść z łańcucha czerwone światło, niechaj suburbia rozogni barwą.

[...] Wieszać psy, wieszać; niech się liczą

w szczękach gięciuchne żebra brokerów,

i niech matkom Polkom trzaskają miednice [podkr. własne].

Łamane ludzkie żebra oraz trzaskające miednice to jedne z licznych przykładów makabrycznych obrazów, które snują się w wyobraźni „ludzi przegrywów”. W ten sposób starają się oni rozładować frustrację i zrekompensować sobie własne życiowe niepowodzenia przez „odegranie się na bezwzględnym świecie” - przynajmniej w marzeniach.

„Przegrywy” to podmioty histeryczne, które nieudolnie próbują dostosować się do świata owładniętego chaosem, pozbawionego stabilizacji i bezpieczeństwa. Przekonanie o życiu we wrogiej rzeczywistości, w której rządzą zasady agresywnego kapitalizmu, wpędzają członków [beep] generation we frustrację wywołaną m.in. niemożnością sprostania wymaganiom systemu lansującego model „człowieka sukcesu” - spełnionego pod kątem zawodowym, rozwojowym, płacowym, prestiżowym itp. W konsekwencji wśród podmiotów wypikanego pokolenia rodzą się makabryczne wizje pełne agresji. Te snute wyobrażenia o przemocy być może mają odwrócić uwagę członków [beep] generation od ich własnej niemocy i przypominać, że w każdej chwili mogą oni przerwać swoją bierność (Skurtys 2017: 68-87). Agresywne marzenia nie przekładają się jednak na zachowanie „ludzi przegrywów”, a tym samym dalej tkwią oni w życiowym marazmie i stagnacji.

\section{NAJBARDZIEJ POGARDZANY ANTYBOHATER [BEEP] GENERATION - „CZŁOWIEK PIZDA”}

Przytoczone przeze mnie wcześniej przykłady z popkultury, mediów i literatury pokazują, że „kultura przegrywu” w Polsce istnieje i, co więcej, obecnie przechodzi rozkwit. We współczesnych zjawiskach muzycznych, publicystycznych, internetowych itp. mamy okazję 
zobaczyć, jak artyści i ich odbiorcy starają się stworzyć wspólną pokoleniową narrację, swoisty język wyrażający podobne problemy polityczne, gospodarcze, społeczne, kulturowe ludzi urodzonych w latach 80. i 90. ubiegłego stulecia.

Niemniej jednak obok potrzeby (s)tworzenia jakiejś wspólnoty opartej na podobieństwie doświadczeń i języka opisującego świat, wśród wypikanego pokolenia istnieje równocześnie silna niechęć wobec perspektywy przynależności akurat do grupy „życiowych przegrywów”. W związku z tym społeczność [beep] generation wykształciła figurę, która miałaby pomóc członkom wypikanego pokolenia w wypełnianiu znienawidzonych przez nich czynności chodzi o „człowieka pizdę”. Sam Tomasz Bąk wypowiada się o tej postaci następująco:

jest superbohaterem do zadań niespecjalnych [podkr. własne] - przede wszystkim niespecjalnie ciekawych. [...] Odwala za mnie całą robotę w social media, tłumaczy się z moich braków i zaniedbań, jest „zderzakiem” [podkr. własne] (że pozwolę sobie wykorzystać określenie z tygodników opinii) - schowany za nim mogę spokojnie wyprowadzić psa na spacer, zagrać próbę z kapelą, napisać wiersz albo spotkać się ze znajomymi. [...] Jego sila wynika wprost $\mathbf{z}$ jego bezsilności [podkr. własne] - choćby nawet chciał (a nie chce), kompletnie nie ma na nic wpływu, wygląda na tyle żałośnie, że nikt nie chce go nawet pobić, zarabia na tyle żałośnie, że nikt nie chce się z nim umówić. Jest pierwszym przegrywem i ostatnią instancją, a z moich obserwacji jasno wynika, że każdy z nas nosi w sobie czasem jego cząstkę [podkr. własne] - chociażby wtedy, gdy chcielibyśmy powiedzieć coś znaczącego, a jesteśmy w stanie powiedzieć tylko „tak, oczywiście” (Glosovitz, Kujawa i Bąk 2019).

Tomasz Bąk w swojej definicji przedstawił główną figurę [beep] generation w świetle ekonomii, polityki, natury kontaktów społecznych bohatera oraz jego aparycji i cech osobowości. „Człowiek pizda” to osoba stojąca najniżej w społecznej hierarchii. Nawet w swojej grupie „ludzi przegrywów” nie doświadcza on uczucia akceptacji, wręcz przeciwnie: jest napiętnowany przez nich tak samo jak przez ogół społeczeństwa. Polski poeta w swoich utworach przedstawia go/ją jako postać nieatrakcyjną, która już samym swoim wyglądem wzbudza litość otoczenia. Wizerunek „człowieka pizdy”, jaki przedstawia w swoich utworach Tomasz Bąk, można odnaleźć również w internecie wśród tworzonych przez anonimowych użytkowników memów (rysunek 2).

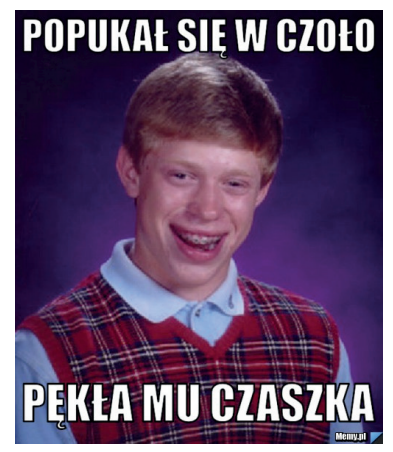

Rysunek 2. Mem przedstawiający wizerunek ,przegrywa”

Źródło: https://memy.pl/mem_554516_popukal_sie_w_czolo 
Figura Tomasza Bąka jest ucieleśnieniem jednych z najbardziej pogardzanych społecznie cech osobowości. Nie chce wyrwać się z bezsilności czy podjąć trudu dokonania zmian we własnym życiu. Podmiot ten sam nie liczy się ze swoim zdaniem i prawdziwymi emocjami, które odczuwa w danym momencie, nie stać go na najmniejszy akt odwagi wyrażenia siebie. W parze z niezbyt interesującą aparycją i osobowością idzie również nieatrakcyjna praca i zarobki. „Człowiek pizda”, bohater późnego kapitalizmu, współtworzy grono prekariuszy, których Guy Standing opisuje jako grupę składającą się:

z wielu milionów ludzi na całym globie, pozbawionych stabilnego punktu zaczepienia. Stają się oni nową klasą niebezpieczną, skłonną słuchać głosów ekstremistów i użyć swoich praw wyborczych oraz pieniędzy do zbudowania dla tych głosów politycznej platformy o rosnącym znaczeniu (Standing 2014: 1).

Zadania, które wypełnia dla zarobku, nie mają żadnych głębszych wartości ani sensu. To, czym się zajmuje bohater [beep] Generation, pomaga mu się utrzymać, lecz niestety nie na poziomie, który dawałby podmiotowi jakieś większe możliwości, czy po prostu satysfakcję. To wszystko odbija się na kontaktach społecznych „człowieka pizdy”. Bohater ten jest wysoce odpychający dla ludzi, którzy żyją w przeświadczeniu o tym, jak niewiele do zaoferowania społeczeństwu ma ta postać. Życie głównego bohatera [beep] Generation toczy się na marginesie społecznym, jego kontakty z innymi osobami ograniczają się do niezbędnego minimum (zwykle do najbliższej rodziny).

„Ludzie przegrywy” pogardzają figurą wykreowaną przez Tomasza Bąka i rozpoznają ją jako potencjalnie zagrażającą ich systemowi wartości, „obciachową”. Pojęcie to należy rozumieć przede wszystkim jako sposób na hierarchizowanie i kategoryzowanie poszczególnych osób, przedmiotów, zjawisk itp. (Burszta 2008: 8). Brak akceptacji „człowieka pizdy” ze strony społeczeństwa odbywa się poprzez uznanie go za „obciachowego” i „wstrętnego”. Jak pisze Julia Kristeva:

We wstręcie przejawia się jeden z owych gwałtownych i mrocznych buntów przeciw temu, co mu zagraża i co, jak się zdaje, nadchodzi z zewnątrz lub rozsadza od wewnątrz, rzucone obok tego, co dopuszczalne, tolerowane, możliwe do pomyślenia. To się narzuca, niepokoi, fascynuje pragnienie, które mimo to nie pozwala się uwieść (Kristeva 2017 : 7).

W związku z tym [beep] generation stara się wyeliminować niepokojącą, a zarazem fascynującą figurę ze sfery społecznej widoczności, a równocześnie wyładować swoją frustrację i agresję na niewinnym podmiocie. Do opisania emocji, jakie towarzyszą przy odbiorze „człowieka pizdy” Tomasz Bąk wykorzystuje zjawisko „obciachowości”, które ma wywołać u odbiorcy antybohatera uczucia zażenowania i zawstydzenia. Autor [beep] Generation kreuje zatem swoją postać na osobę możliwie najbardziej odpychającą, wystawiającą na próbę wartości wyznawane przez społeczeństwo. Już sama nazwa: „człowiek pizda”, wulgarna, trudna do wypowiedzenia na głos bez uczucia zażenowania, piętnuje podmiot, nadaje mu cechy śmieszności.

W związku z dotychczasowymi rozważaniami na bohatera Bąka można spojrzeć w perspektywie kategorii „Nikogo”, a więc osoby, która ogniskuje upodlenie, degradację, upadek fizyczny, duchowy czy społeczny. Pozornie, jak zauważa Anna Figa, przedstawiony typ 
postaci nie sugeruje podobieństwa między sobą a odbiorcą. Niemniej jednak sytuacja ulega komplikacji, gdy wypikane pokolenie uświadamia sobie, że mimo odczuwanego wstrętu próby nabranie dystansu do figury Bąka okazuje się czymś niemożliwym do osiągnięcia. „Nikt może być także Każdym. [...] Nikt odsłania to, co w nas ukryte, wstydliwe, do czego nie chcemy się przyznać przed innymi i samymi sobą" (Figa 2015: 393-301). W konsekwencji z jednej strony dzięki tej postaci „frajera” (Miejski Słownik Slangu i Mowy Potocznej 2019), „ciamajdy, niezdary” (Czeszewski 2006: 234) środowisko [beep] generation może zaznać, choćby w ograniczonym stopniu, życia prowadzonego przez ogół społeczeństwa.

„Człowiek pizda” dobrowolnie wyręcza ludzi ze swojego środowiska od wykonywania przez nich najbardziej pogardzanych i nudnych obowiązków. Dzięki temu członkowie wypikanego pokolenia mogą konstruować swoją tożsamość w opozycji do wykreowanej przez Tomasza Bąka figury, a tym samym stawiać się względem niej wyżej w hierarchii społecznej. $\mathrm{Z}$ drugiej strony postać przedstawiona przez współczesnego poetę obnaża, jak bardzo bohater ten jest społeczeństwu niezbędny. Gdyby nie on, ktoś inny musiałby zająć najniższe miejsce w społeczeństwie i podjąć się wykonywania żmudnych, bezsensownych zadań. „Człowiek pizda" jest więc swoistym gwarantem poczucia bezpieczeństwa i komfortu, co irytuje jego środowisko. Postać ta jest jednym z elementów podtrzymujących społeczną hierarchię, przez co zostaje obnażona kruchość i umowność tej ostatniej - utrzymanie systemu zostało uzależnione od istnienia i funkcjonowania w świecie „człowieka pizdy”: „obciachowego” abjektu - społecznej tkanki, która budzi wstręt, a której nie da się usunąć ze społeczeństwa (zob. Kristeva 2017). W rezultacie antybohater, mimo wyraźnego sprzeciwu swojego środowiska, jest najbardziej widocznym i rozpoznawalnym członkiem wspólnoty „ludzi przegrywów” i w komiksowym stylu funkcjonuje jako „superbohater do zadań niespecjalnych” właśnie, jak go nazwał sam Tomasz Bąk. Nie ma możliwości wyeliminowania „człowieka pizdy” z rzeczywistości nakreślonej przez autora [beep] Generation, ponieważ „Nikt” staje się w tym przypadku „szczególnym Każdym” (Figa 2015: 393-301) i jak w teorii abjektu Julii Kristevej (zob. Kristeva 2017), „każdy z nas nosi w sobie czasem jego cząstkę” (Glosovitz, Kujawa i Bąk 2019). W związku z tym żaden bohater tomiku wierszy Tomasza Bąka, a nawet sam autor i jego czytelnicy nie mogą pozostać obojętni wobec przedstawionego antybohatera „ludzi przegrywów”, zwłaszcza w sytuacji, kiedy „chcielibyśmy powiedzieć coś znaczącego, a jesteśmy w stanie powiedzieć tylko »tak, oczywiście «” (Glosovitz, Kujawa i Bąk 2019).

Podsumowując dotychczasowe rozważania o „człowieku piździe”, można określić go jako doskonały produkt systemu społecznego: to zawsze podporządkowany, karny pracownik, który posłusznie wykona każde zlecone mu zadanie. Niemniej jednak istnieje również drugie oblicze tej postaci. Figura Bąka jest również niepożądanym, „ubocznym” efektem mechanizmów rynku kapitalistycznego. Świat ten nie składa się przecież z samych ,zwycięzców”, nie każdy osiągnie sukces zawodowy, materialny czy społeczny. Urynkowiona rzeczywistość lansuje „wygranych”, ekskluzywne grono, których plany akurat się powiodły. Cała reszta społeczeństwa: tzw. ,pprzegrani” zostają zepchnięci poza obręb społecznej widoczności. Istnienie „człowieka pizdy” i zyskiwana przez niego popularność, „przegrywy”, które zaczęły wykraczać poza swoją peryferyjność i przedostawać się do kulturowego centrum, są więc niebezpieczni dla systemu, ponieważ stanowią jawny dowód jego niedoskonałości, podważają jego prawomocność i perfekcyjność, co świadczy o subwersywnym charakterze 
„kultury przegrywu”. Wspólnota wykluczonych oddziałuje „oddolnie” na szeroko pojęty system społeczno-ekonomiczny i niejako rozbija jego skostniałe elementy z wnętrza tej rzeczywistości, dokładnie, jak w mechanizmie subwersji (Skowronek 2011: 30-40). Stąd też to członkowie wypikanego pokolenia $\mathrm{z}$,człowiekiem pizdą” na czele są postrzegani jako osoby zagrażające dotychczasowemu ładowi społecznemu, przez co zostają całkowicie obarczeni winą za swoje niepowodzenia (,jeśli nie odniosłeś sukcesu, to znaczy, że za mało się starałeś"), odpowiedzialność za poniesione porażki spada na nich, nie zaś na system, społeczeństwo, rynek itp.

\section{KONTROWERSJE I NIEJEDNOZNACZNOŚĆ „KULTURY PRZEGRYWU”. ZNACZENIE SPOŁECZNE, EKONOMICZNE, POLITYCZNE I KULTUROWE}

Na podstawie dotychczasowych obserwacji i rozważań można nakreślić wstępną definicję zjawiska, które funkcjonuje już w potocznej, szerszej świadomości społecznej i jest określane mianem „kultury przegrywu”. Przez to pojęcie rozumiem krystalizujące się co najmniej od dwudziestu lat specyficzne środowisko antybohaterów, niepożądanych Każdych, zbiorowisko obciachowych i wstrętnych podmiotów-frustratów, którzy wypracowali charakterystyczny dla siebie sposób bycia, język oraz światopogląd. Zwiększająca się popularność grupy „przegrywów" ma oczywiście swoje konsekwencje społeczne, ekonomiczne, polityczne i kulturowe.

\section{KONSEKWENCJE SPOŁECZNE I EKONOMICZNE}

„Kultura przegrywu” przede wszystkim silnie oddziałuje na przyjętą w społeczeństwie polskim ustaloną odgórnie hierarchię wartości. Zjawisko „przegrywu” pojawiło się jako odpowiedź na panującą zasadę utożsamiania sukcesu z zyskiem, a przegraną z brakiem umiejętności akumulowania bogactwa (Halberstam 2018: 132). Społeczność żyjąca według zasad kapitalistycznych uznaje rywalizację z innymi jako drogę do osiągnięcia pożądanego statusu społecznego i ekonomicznego (Sadulski 2018). Ten model narzuconej egzystencji jawi się więc jako nieustanna walka o pozycję w społecznej hierarchii i dobra materialne.

Życie ponowoczesne ,[...] nie zostawia miejsca na myślenie o czymś, czego nie można, przynajmniej teoretycznie, spo-żyć i prze-żyć bezzwłocznie, tu i teraz” (Bauman 2017: 15). W rezultacie rzeczywistość kapitalistyczna przekonuje, że posiadany kapitał to główny czynnik sprawdzający i udowadniający wartość uczestników życia codziennego (zob. Świda-Ziemba 1998). Według Zygmunta Baumana współcześnie panuje przekonanie, że człowiek jest tym, co kupuje, a granice między aktami konsumpcji a innymi aspektami życia ulegają zatarciu (Bauman 2011: 90). Takie idee jak moralność czy drugi człowiek odchodzą na dalszy plan, liczy się zaś status społeczny potwierdzony odpowiednią ilością przedmiotów materialnych.

W związku z tak funkcjonującą rzeczywistością wybór dokonywany przez członków społeczeństwa ogranicza się w zasadzie do dwóch dróg życiowych: wypełnianie społecznego skryptu kulturowego pozwala jednostce postrzegać się jako spełnioną lub podmiot nie dostosowuje się do reguł narzuconych przez system i wówczas nie może myśleć o sobie jako o „człowieku sukcesu”. W konsekwencji współczesna definicja „zwycięstwa” przyjęta przez 
społeczeństwo zaczyna uchodzić za męczącą, utopijną, niemożliwą do zdobycia lub osiąganą zbyt dużym kosztem (moralnym, egzystencjalnym). Sposób postrzegania „sukcesu” coraz częściej zostaje poddany krytyce przez poszczególnych członków wspólnoty wykończonych chaotyczną codziennością.

W konsekwencji zjawisko „kultury przegrywu” oferuje swoim odbiorcom „świat przestawiony" (Bąk 2016: 45, zob. Kaczmarski i Koronkiewicz 2016: 99) - przestawionych wartości - życiowych celów obieranych wbrew odgórnie przyjętemu skryptowi kulturowemu. Codzienność społeczności „przegrywów”, na którą składa się powiększanie kapitału oraz budowanie własnej marki rynkowej, zostaje ukazana jako niebezpieczne „markowanie rzeczywistości” (Kaczmarski i Kopyt 2017), a więc przekłamywanie jej: kreowanie sztucznego świata potrzeb. Status społeczny i nagromadzone dobra materialne prezentowane w „markowanej rzeczywistości” jako konkretne i namacalne „kultura przegrywu” przedstawia jako abstrakcyjne i pozorne.

\section{KONSEKWENCJE POLITYCZNE}

„Ludzie przegrywy” to osoby zmęczone i sfrustrowane swoją sytuacją społeczno-ekonomiczną: prekarnością związaną z różnymi formami wspólnotowej niepewności, poczucia nieustannego zagrożenia, stresu i niestabilności na rynku pracy (Kaczmarski 2017: 98-110). Nie zgadzam się w tym miejscu z tezą Standinga, który twierdzi, że: ,prekariat ma już za sobą etap, w którym tworzyły go przygnębione masy przegranych ludzi doświadczających niepewności i deprywacji oraz okazjonalnych, podnoszących na duchu działań pierwotnych buntowników” (Standing 2015: 385). Stwierdzenie to wydaje się nie odnosić do sytuacji w Polsce. Niespełnienie i sfrustrowanie „ludzi przegrywów” sprawia, że zaczynają oni poszukiwać skrajnych rozwiązań ich aktualnej życiowej sytuacji w naszym kraju. Zdaniem Tomasza Bąka „kultura przegrywu” demonstruje tu swój niebezpieczny potencjał: jej członkowie mogą zapragnąć wypełnić ideową pustkę, a także przekuć swoją frustrację i agresję w czyn przez poparcie radykalnych modeli o charakterze politycznym, co przejawia się na przykład wstąpieniem do skrajnie prawicowego ugrupowania - Obozu Narodowo-Radykalnego (ONR). Należy pamiętać, że w takim przypadku przyjęcie radykalnych poglądów przez „przegrywów” zwykle odbywa się biernie: nie konstruują oni samodzielnie swoich tożsamości, lecz korzystają z gotowych schematów politycznych. Ponadto często sam wybór tego typu modelu zachowania nie świadczy o jego faktycznej realizacji w życiu codziennym. Jak już zostało wspomniane, „kultura przegrywu” jest kulturą podmiotów, którzy nie potrafią wyjść ze sfery swojej potencjalności i biernie tkwią w chaotycznej rzeczywistości - ich (nikłe) głosy sprzeciwu są ignorowane.

\section{KONSEKWENCJE KULTUROWE}

Warto zwrócić uwagę, że kultura „ludzi przegrywów” z jednej strony ma w pewnych sytuacjach charakter aktywny. Z drugiej zaś „,kultura przegrywu” przejawia swoją pasywność: zobojętnienie i wycofanie się z życia politycznego czy społecznego to główne jej cechy. Życie podmiotów przegranych należy definiować przede wszystkim przez pryzmat ich bierności, 
której źródłem jest podporządkowanie się odgórnie narzuconemu skryptowi społecznemu, ekonomicznemu, politycznemu. W konsekwencji zdaniem Richarda Senneta:

we współczesnym społeczeństwie rodzi się specyficzny typ charakteru: osobowość niezdolna do radzenia sobie $\mathrm{z}$ wymagającymi, złożonymi formami społecznego zaangażowania, wycofana, pozbawiona pragnienia wspólpracy z innymi. Nazwę ją tu ,ja” niekooperacyjnym [podkr. własne] (Sennet 2013: 235).

„Kultura przegrywu”, mimo że wydobywa swoje podmioty ze społecznej przezroczystości, nie wykształciła mechanizmów, które pozwoliłyby jednostce podjąć się samodzielnego buntu. Po wydobyciu z siebie „,bluzgu”, wyładowaniu frustracji w agresywnych wizjach końca świata wspólnota przegranych powraca do znienawidzonej przez siebie rzeczywistości.

Społeczność „przegrywów” nie stawia czoła swoim problemom, przez co udaje im się tymczasowo oddalić od siebie poczucie niepokoju. „Kultura przegrywu” wrzuca swoich członków w zobojętnienie: podmioty te wolą oficjalnie przyjąć postawę, że jest im „wszystko jedno”, uznają każdy element otaczającej ich rzeczywistości za podobnie tandetny, „obciachowy" i niegodny uwagi, jak w wierszu Tomasza Bąka Tomaszów jest jak hand job:

Dopatrujemy się w rozkładzie prawdopodobieństw,

a nie w zachodach słońca, choć te

nad tomaszowską riwierą bywają równie urocze.

I nawet nie próbujemy wyobrażać sobie innych

nauczeni doświadczeniem, że wszystko chuj [podkr. własne] (Bąk 2016: 9-10).

Dobrowolnie przyjęta pasywność przez ,ja” niekooperacyjne pozwala społeczności „,przegrywów" odsunąć od siebie poczucie odpowiedzialności za swoją sytuację egzystencjalną i nie zastanawiać się nad niepokojącą przyszłością.

Równocześnie warto w tym miejscu podkreślić, że „kultura przegrywu” nie ma wyłącznie charakteru pasywnego. Zjawisko to może stać się elementem kultury oporu, jednak na innych zasadach, niż tych wylansowanych przez kontrkulturę lat 60. ubiegłego wieku w Ameryce ze swoimi postulatami indywidualizmu, kreatywności, autentyzmu i ekspresji, które z kolei zostały wchłonięte przez kulturowy kapitalizm (Sowa 2010: 11-23), przerobione na gotowe strategie tożsamościowe, a w konsekwencji odarte ze swojego wywrotowego potencjału. Co więcej, Rafał Drozdowski podkreśla, że przyjęcie postawy buntowniczej bardziej reprodukuje reguły zastanego porządku, niż je przekształca: wszelkie roszczenia wysuwane względem władzy legitymizują i umacniają ją na swojej pozycji (Drozdowski 2010: 24-34). Zygmunt Bauman wysuwa wręcz następujące wnioski:

Konformizm, obwiniany kiedyś o dławienie indywidualności człowieka, uznawany jest dzisiaj za największego sprzymierzeńca jednostki. A właściwie za jedynego, na którym można polegać. [...] Walka o wyjątkowość stała się dzisiaj głównym motorem napędowym masowej produkcji i masowej konsumpcji (Bauman 2007: 40).

Mając na uwadze powyższe rozważania, można wysunąć tezę, że „kultura przegrywu” ma w sobie ogromny potencjał subwersywny. Zanurzona we współczesnej rzeczywistości i jej 
oficjalnie przyjętych normach [beep] generation samym swoim istnieniem zmienia niejako „od wewnątrz” charakter tego, co dominujące, ugruntowane, skostniałe. Społeczność „przegrywów”: jej „obciachowość”, abjektalność i rosnąca popularność (wychodzenie ze sfery społecznej niewidzialności) drażni ogół społeczeństwa, każe konfrontować się im z tym, co odpychające i żenujące, wprawia je w dyskomfort, podważa przyjęte przez nich wartości, obnaża chaos i kiczowatość zastanej rzeczywistości. Ponadto ważną rolę odgrywa tu antybohater marginalnej wspólnoty - „człowiek pizda”. Jego swoiste nie-działanie i „zgoda na wszystko" powodują, że nie można rozpatrywać tej figury w kontekście hierarchii społecznej, ponieważ podmiot ten do niczego nie dąży, biernie przyjmuje zastaną rzeczywistość, a więc nie kieruje się wartościami wyznaczanymi przez społeczeństwo. Tym samym „człowiek pizda” utrudnia środowisku umieszczenie go na którymś ze szczebli zbudowanej przez nie hierarchii, co wprowadza nieład w pozornie uporządkowaną codzienność odbiorców.

Co więcej, sama grupa „przegrywów” nie pozostaje obojętna na nie-działanie figury wykreowanej przez Bąka. Wstręt, jaki wzbudza „człowiek frajer”, jego „obciachowość” i antybohaterskość dobitnie pokazują i uświadamiają przegranej wspólnocie ich egzystencjalne problemy. Figura ta przerywa bierność i obojętność środowiska „kultury przegrywu”: wpływa na odczuwane przez nich emocje (frustracji, agresji), zmusza do zajęcia wobec siebie określonego stanowiska, a równocześnie nie pozwala zapomnieć o swojej „niezbędności”. W końcu jeśli „człowiek pizda” nie wypełniałby najbardziej pogardzanych społecznie zadań, ktoś inny musiałby przejąć jego funkcję, do czego środowisko „przegrywów”, pogrążone w lęku przed działaniem, prawdopodobnie nie byłoby zdolne.

\section{KULTURA PRZE(GRY)WU - Z(GRY)WANIE SIĘ - KULTURA UDZIAŁU. PODSUMOWANIE}

Z pewnością nie można zignorować rosnącej popularności „ludzi przegranych” we współczesnej popkulturze i nie tylko. Generacja Nic, [beep] generation, Pokolenie Tamagotchi to tylko jedne z licznych przykładów dokonującej się na oczach swoich odbiorców zmiany narracji o społeczności ludzi urodzonych w latach 80. i 90. XX wieku. Współczesne społeczeństwo, dręczone kapitalistycznymi wymogami pogoni za karierą, sfrustrowane faktem, że wartość człowieka jest mierzona ilością posiadanych przez niego dóbr, zmęczone coachingiem i poradnikami w stylu ,jak zarobić swój pierwszy milion” (Bąk 2016: 41-42), powoli odwraca się od self-made mana w stronę „człowieka porażki” (Sadulski 2018) - „,człowieka pizdy”. Wydaje się, że to, co dawniej uchodziło za „obciachowe”, żenujące, budzące wstręt, dzisiaj zaczyna być akceptowane, a nawet afirmowane.

Można stwierdzić, że „kultura przegrywu”, nieustannie oscylująca między konformizmem, biernością a specyficzną sprawczością, „performatywnością”, oporem i subwersją, to nie tylko „przegrana”. Ważnym komponentem opisywanego przeze mnie zjawiska jest coś, co określam nieustanną potrzebą ,zgrywania się”. Jest to ciągła próba podejmowania gry podmiotu ,przegrywu” ze swoim odbiorcą. Człowiek należący do tej niszowej kultury zakrywa swoją frustrację i agresję postawą, która traktuje świat i jego wartości „nie na serio”. Brak powagi wprowadza element śmieszności do „kultury przegrywu”, której członkowie stosują 
narzędzie potrójnej ironii: względem społeczeństwa, swojego środowiska, jak i siebie jako pojedynczych jednostek. „Zgrywanie się” i jej prześmiewczy charakter pozwala podmiotom „,zgrywać kogoś, kim się nie jest”, czyli na przykład tymczasowo przyjąć na siebie maskę „człowieka pizdy”. Podjęcie przez wspólnotę przegranych tej gry z odbiorcą i z samymi sobą pozwala im w pewien sposób zmierzyć się ze swoją przegraną, spróbować ją oswoić (przez siebie i społeczeństwo).

Ponadto ta aktywność w bierności zgrywających się członków „kultury przegrywu” uniemożliwia jej jednoznaczne rozpatrzenie w kontekście prostych pojęć, takich jak: konformizm lub opór, pasywność lub działanie. To wszystko każe spojrzeć na omawiane zagadnienie nie w perspektywie uczestnictwa/nieuczestnictwa, ale w kontekście udziału (Nycz 2017: 59):

Ta kultura partycypacji, w którą zdaje się weszliśmy, ma też swoje konsekwencje. Uwrażliwia na rozmaite formy udziału, także bezwiednego, na dwuznaczność pozycji świadka, biernego widza (stymulując, jak sądzę, m.in. współczesną refleksję nad historycznymi przejawami pozycji bystandera w czasach Zagłady), na trudność - jeśli nie niemożliwość - obsadzenia (się) w roli niezaangażowanego obserwatora

„Kultura przegrywu” jest to pewien typ wymuszonej partycypacji, która każe skorzystać odbiorcy z nowego sposobu brania ,udziału” w świecie zdominowanym przez kapitalistyczne ujęcie zwycięstwa.

Niewątpliwie niniejsze rozważania przedstawiają jedynie niewielką część pojęć i problemów związanych z omawianym zagadnieniem szeroko pojętego ,pprzegrywu”. W Polsce problem ten jest wciąż interesujący i stale się rozwija. Tym samym każda próba wydobycia cech charakterystycznych „kultury przegrywu” zdaje się ryzykowna, ale i potrzebna. Kultura ta zasługuje na dalsze badania i wnikliwą obserwację.

\section{BIBLIOGRAFIA}

Bauman, Zygmunt. 2007. Plynne życie, Kraków: Wydawnictwo Literackie.

Bauman, Zygmunt. 2011. 44 listy ze świata płynnej nowoczesności, Kraków: Wydawnictwo Literackie.

Bąk, Tomasz. 2016. [beep] Generation, Poznań: Wydawnictwo Wojewódzkiej Biblioteki Publicznej i Centrum Animacji Kultury.

Burszta, Wojciech Józef. 2008. Czy obciach jest uniwersalny?, w: Jacek Nowiński (red.), Moda na obciach, Elbląg: Wydawnictwo Wilk Stepowy.

Cool Kids of Death. 2002. Cool Kids of Death, CD, Warszawa: Sissy Records.

Czeszewski, Maciej. 2006. Słownik polszczyzny potocznej, Warszawa: Wydawnictwo Naukowe PWN.

Drozdowski, Rafał. 2009. Obraza na obrazy. Strategie społecznego oporu wobec obrazów dominujących, Poznań: Zysk i S-ka.

Drozdowski, Rafał. 2010. Kultury na jałowym biegu. Uwagi na temat ograniczeń i perspektyw kultur oporu w społeczeństwie poszukujacych nowych form uspołecznienia, „Kultura Współczesna", 2: 24-34. 
Dziamski, Grzegorz. Wartościa sztuki krytycznej jest to, że wywołuje dyskusje, „Gazeta Malarzy i Poetów", 2-3: 39-40, http://witryna.czasopism.pl/gazeta/drukuj_artykul.php? id_artykulu=56 [26.11.2019]

Figa, Anna. 2015. Nikt - nowy Każdy polskiej prozy najnowszej? Figura wyparcia, wstrętu i obrzydzenia, w: Wanda Dittrich, Mariusz Hybiak, Mariusz Wirski i Magdalena Zegarlińska (red.), Wstręt i obrzydzenie, Gdańsk: Wydawnictwo Uniwersytetu Gdańskiego.

Glosovitz, Monika, Dawid Kujawa i Tomasz Bąk. 2016. To nie jest kolejna rozmowa dla oswojonych, „ArtPapier”, 3, http://artpapier.com/index.php?page=poezja\&wydanie=296 [26.11.2019].

Halberstam, Jack. 2018. Przedziwna sztuka porażki, Warszawa: Wydawnictwo Krytyki Politycznej.

Januszkiewicz, Michał. 2008. Obciach jako kategoria kulturowo-społeczna, w: Jacek Nowiński (red.), Moda na obciach, Elbląg: Wydawnictwo Wilk Stepowy.

Kaczmarski, Paweł. 2017. Trzy zgrzyty albo o prekarności w nowej poezji, w: Tomasz Dalasiński i Klaudia Muca (red.), Doświadczenie negatywne w poezji polskiej XXI wieku, Toruń: Inter. Literatura - Krytyka - Kultura.

Kaczmarski, Paweł i Marta Koronkiewicz (red.). 2016. Zebrało się śliny, Wrocław: Biuro Literackie.

Kaczmarski, Paweł i Szczepan Kopyt. 2017. Jaśnierynek. (Spóźnione) uwagi o „, [beep] generation”, „Praktyka Teoretyczna”, 5 maja.

Kristeva, Julia. 2007. Potęga obrzydzenia. Esej o wstręcie, Kraków: Wydawnictwo Uniwersytetu Jagiellońskiego.

Łebkowska, Anna. 2011. Jak ucieleśnić ciało: o jednym z dylematów somatopoetyki, „Teksty Drugie", 4: 11-27.

Masłowska, Dorota. 2018. Inni ludzie, Kraków: Wydawnictwo Literackie.

Miejski słownik slangu i mowy potocznej, https://www.miejski.pl/ [26.11.2019].

Najder, Łukasz. 2018. Przegryw: Przegraj jak najlepiej, „Dwutygodnik”, https:/www.dwutygodnik.com/artykul/7735-przegryw-przegraj-jak-najlepiej.html [25.12.2019].

Nycz, Ryszard. 2017. Kultura jako czasownik. Sondowanie nowej humanistyki, Warszawa: Instytut Badań Literackich PAN.

Pęczak, Mirosław. Meandry popkultury, „Polityka”, https://www.polityka.pl/tygodnikpolity$\mathrm{ka} / \mathrm{kultura} / 282872,1$,meandry-popkultury.read?page=8\&moduleId=5311 [26.11.2019].

Ronduda, Łukasz. Strategie subwersywne w sztukach medialnych, Kraków: Wydawnictwo RABID.

Sadulski, Bartosz. 2018. Przegryw: Beata Pawlikowska od Depresji. Rozmowa z Kamilem Fejferem, Małgorzata Halber, Pawłem Żukowskim, „Dwutygodnik”, https://www.dwutygodnik.com/artykul/7732-przegryw-beata-pawlikowska-od-depresji.html [25.11.2019].

Sennet, Richard. 2013. Razem. Rytuaty, zalety i zasady wspótpracy, Warszawa: Warszawskie Wydawnictwo Literackie MUZA SA.

Skowronek, Katarzyna. 2011. Językoznawstwo subwersywne, „Annales Academiae Paedagogicae Cracoviensis", 107: 30-40.

Skurtys, Jakub. 2017. Widma terroryzmu w polskiej poezji najnowszej, w: Tomasz Dalasiński i Klaudia Muca (red.), Doświadczenie negatywne w poezji polskiej XXI wieku, Toruń: Inter. Literatura - Krytyka - Kultura, s. 66-87. 
Sowa, Jan. 2010. Co jest wywrotowe? Prus w Audi, Marks w telewizji?, „Kultura Współczesna", 2: 11-23.

Stępniak, Grzegorz, Siła queerowej porażki, „Polish Theatre Journal”, 1-2: 1-13.

Śliwiński, Piotr. 2019. Po co Poznań Poetów? By stanać z rzeczywistością twarza w twarz, https:// poznan.wyborcza.pl/poznan/7,105531,24790985,twarza-w-twarz.html [25.11.2019].

Świda-Ziemba, Hanna. 1998. Wartości egzystencjalne młodzieży lat dziewięćdziesiątych, Warszawa: Zakład Socjologii Moralności i Aksjologii Ogólnej, Instytut Stosowanych Nauk Społecznych Uniwersytetu Warszawskiego.

Taconafide. 2018. Soma 0,5 mg, CD, Warszawa: Nobocoto Studio.

Taras, Katarzyna. 2012. Frustraci. Bohaterowie filmowi i literaccy wobec polskiej rzeczywistości po 1989 roku, Warszawa: Wydawnictwo Uniwersytetu Kardynała Stefana Wyszyńskiego.

Wandachowicz, Jakub. 2012. Generacja Nic, „Gazeta Wyborcza”, https://wyborcza.pl/ 1,75410,10939975,Generacja_Nic.html [25.11.2019].

Wolski, Michał. 2016. Wampir antybohaterem? (Próżne) zmagania z rola superbohatera na przykładzie Morbiusa, żywego wampira, „Kultura Popularna”, 3: 36-47.

\section{"LOSER CULTURE” AND [BEEP] GENERATION BASED ON POETIC WORKS BY TOMASZ BĄK}

In my article I want to focuse on phenomenon which functions as "loser culture". In addition, the purpose of these thoughts will be characteristics untypical community of "losers" and their the most recognizable antihero, whose Tomasz Bąk called "human cunt". The basic example belonging to the broadly defined "loss" will be the poetic work of the contemporary Polish poet: Tomasz Bąk. The starting questions for my thoughts will be the following fundamental problems:

1. Did the phenomenon of "loser culture" really occur in Poland?

2. If so, what is it and what are its characteristics?

3. Who are the community of "losers" and the "human cunt"?

4. What social, economic, political and cultural consequences do the phenomenon have?

I hope that the answer to the mentioned problems help to characterize "loser culture".

Key words: activity, resistance, Passivity, "loser culture", [beep] generation, "human cunt"

Zgłoszenie artykułu: 28.11.2019

Recenzje: 7.01.2020

Rewizja: 16.01 .2020

Akceptacja: 1.02 .2020

Publikacja on-line: 30.03 .2020 